\title{
Factors Affecting Audit Judgement
}

\author{
Cicely Delfina Harahap ${ }^{1}$, Aina Zahra Parinduri ${ }^{2}$ \\ \{cicely@trisakti.ac.id ${ }^{1}$, ainaparinduri@trisakti.ac.id² \\ Fakultas Ekonomi dan Bisnis Universitas Trisakti, Jakarta, Indonesia ${ }^{1,2}$
}

\begin{abstract}
This study proposes to analyze and describe the effects of independence, competence, and audit experience on audit judgment with task complexity as moderating variable. This study also uses primary data by distributing questionnaires to Jakarta city auditors. Subsequently, 115 samples were generated using random sampling, and a series of tests were performed, including validity, reliability, multiple linear regression, $\mathrm{F}$ and T-tests. Independence and audit experience was then observed to positively influence the judgement of an auditor while competency has no impact. Task complexity strengthens the influence of independence, competence on audit judgment, On the other hand, task complexity weakens the influence of audit experience on audit judgment.
\end{abstract}

Keywords: Audit Judgement; Audit Experience; Competence; Independence; Task Complexity

\section{Introduction}

An auditor is an individual appointed to review and verify financial records. In general, the judgement of an audit significantly affects opinion offered by an auditor. The phenomenon of audit judgment is one of the evidence regarding the sale and purchase of unqualified opinions in the audit of the financial statements of Badan Pemeriksaan Keuangan (BPK), private companies, and Badan Usaha Milik Negara (BUMN) audited by the accounting firm public. Several KAPs are known to trade stamps which state that they are unqualified opinions for companies that need a credit or to be reported to regulators such as cooperatives that must report to the ministry [1].

Auditors reputations can be maintained mainly through preventing audits failure cases, which impact the future negatively, including loss of jobs, public mistrust, social credibility and lawsuits. [2]. Because of this, the auditor is required to maintain the trust obtained from the client (company) by maintaining accountability and professionalism. An auditor the audit process provides an opinion with judgment based on past, present, and future events [3].

As happened in real estate companies, The Financial Services Authority (OJK) sanctioned the one-year freeze to the partner public accounting firm of Ernst and Young (EY) because it was considered not thorough in the presentation for the financial statements Dec 31, 2016 of PT Hanson International Tbk (MYRX). Public Accounting Firm Purwantono, Sungkoro, and Surja were proven to have committed violations of Pasal 66 of UUPM JIS. paragraph A 14 SPAP SA 200 and Section 130 of the Code of Ethics of the Public Accountant Profession. 
Mistakes made the overstatement of Rp 613 Billion due to revenue recognition with full accrual method for transaction with a gross value of $\mathrm{Rp} 732$ Billion. In addition, the financial statements also do not disclose the existence of a Sale and Purchase Agreement on ready-tobuild on July 14, 2019 conducted by Hanson International. (https://www.cnbcindonesia.com/).

Research on audit judgment has been carried out by [1], [2], [4]. The findings indicate that auditor's judgement is positively affected by their experience and tax complexity [5]. In Takiah, negative impacts of task complexity on audit judgement performance is clearly stated. Results showed that expertise and independence auditors contribute positively on auditor's judgement [6] which is a subjective consideration of an auditor led into inconsistency of research results depending on a person view of situation, requiring additional empirical evidence regarding the factors that influence the auditor in making a judgment.

Theoretically, results should contribute to ideas enriching insights to impact self-reliance, proficiency, and experience of auditors on audit judgment with task complexity as a moderating variable. Practically this study can be used as a reference by auditors in relation to audit judgment, and contribute to the government as material for policy considerations regarding the issue of audit judgment.

\section{Theory Framework and Hypotheses}

\subsection{Behavioral Decision Theory}

Behavioral decision theory associated with behavioral economics and finance that can be applied to political science is a descriptive psychological theory of human judgment in decision making [7]. Behavioral Decision Theory look into individuals' decision-making attitude. Auditors' decision-making process depends on aspects such as knowledge levels and auditors experience. Different levels of knowledge and experience correlate when making audit judgments in decision making. The right decision will be obtained by the auditor when applying behavioral decision theory to choose one of the two alternatives selection. [8].

Senior auditors have more experience and knowledge of general education, special education, and training in the field of auditing while young auditors have finalized their studies and lack any experience. The difference in knowledge and experience of the auditor will be very influential in providing an assessment. Therefore, it is important to understand the behavior of auditors in processing information to make audit judgements. [9].

\subsection{Independence}

One of the most important principles of integrity and objectivity for an auditor is independence which is a character that is hardly influenced and controlled by the rest and express his opinion after considering whether all the information obtained is material or not. Auditors need to be honest to the mangers and companies owners, creditor and users who trust audit statements[10], SA Section 220, PSA No.4, p. 220.1). Their feasibility of financial statement will be questioned in a case of biasness against any party [11].

Public accountants should be independent and not easily influenced in performing their responsibilities. Independence can be perceived as the period spent with a client (audit tenure), which is minimized by Indonesia government to the auditors for a maximum of 3 years and 5 years for Public Accountants Firm (KAP).. [12]. Therefore, this is so that the auditor is not too close to the client to prevent accounting scandals. 


\subsection{Competence}

The ability of an auditor to use knowledge and experience from auditing to perform respective duties carefully and objectively is known as auditor competency. The first general standard SA 210 [10] mentions that professional competency maintenance. High competency level results into good audit quality. UU NO.5 states that auditors should maintain their competencies through continuous professional training. Competency comprises of character, general knowledge and unique techniques that enhances expertise, resulting to productive audit.

\subsection{Experience}

This is the entire period an auditor has spent in auditing. Organizations experience is time spent with the auditor and the audit team performing a specific role beginning from beginner level up to the top in the audit institution and interrelate with all groups and parties with every dynamic it faces. [13].

Experiences may differ among auditors, this difference being due to the varying structure of the team, and personal client. Experienced auditors have special understanding and work experience for process audits, standards used as a reference, environmental audits, audit issues, and financial accounting. Auditors experiences including service length, task frequency and rotations experienced are measured using an indicator. The classification of auditor experience consists of audit experience with specific clients, experience in specific industries, and financial audit experience. Experience with specific clients is obtained from working relationships over a certain period through understanding the client's organizational culture, models, and operations, then, industry experience is the auditor's expertise gained by serving in one or several industries [14].

\subsection{Task Complexity}

According to [15] task complexity is a wide term explaining how a task characteristics impacts the cognitive demands used on task performer. Recent studies have found different definitions that are divided into 5 general classes of complexity:
a. As a source of difficulty
b. As a source of information processing requirements
c. Result from lack of task structure
d. As a measure of problem space characteristics
(e.g., number of paths, amount of required knowledge)

e. As an objective function of task characteristics

(e.g., number of task elements, degree of interrelationship between elements, dynamics of task objectives

The job as an auditor has a high level of complexity and difficulty, be a professional as an auditor must have special abilities, if the auditor is not competent in his field, the task complexity will increase very influential on the audit opinion given by the auditor. The understanding and assignment task of the auditor is expected to be able to complete his duties according to the specified time without error. The auditor's ability is expected can overcome 
problems related to task complexity [4].

\subsection{Audit Judgment}

The definition of judgment according to [16] "Auditing is the accumulation and evaluation of evidence about information to determine and report on the degree of correspondence between the information and established criteria". To elaborate, "Auditing is an activity that collects and evaluates evidence about information to determine and report the degree of conformity between that information and the criteria that have been applied" [16], [1]. Professional Standards of Public Accountants (Indonesian Institute of Public Accountants, 2011) section 341 (Auditor's Consideration of the Entity's Ability to maintain Its Survival) mentions the Audit judgment on the ability of business entities in maintaining. Its survival must be based on the absence of doubts from the auditor's self. Owning the ability of a unitary effort in maintaining continuity life within one year from the date of the audited financial statements.

Audit judgment is an activity that is needed by auditors in carrying out their duties, especially in auditing the financial statements of a company. The audit judgment depends on the receipt and development of that evidence as to produce confidence arising from the auditor's ability to explain the evidence described [9]. To make a judgment, the auditor must evaluate the evidence collected. The evidence must be valid and relevant which the auditor would use to express an assumption on the audited financial statements so that the audit assessment determines the results and quality of the audit. Then, it will show how the performance of an auditor [17].

Audit judgment is a decision issued by the auditor [18]. Audit judgment has an important role in the formation of audit opinions[19]. Making judgment audits requires skills gained through long learning the basis of the audit knowledge is obtained through learning in the village [20]. Other opinions according to [21] "Auditor judgment is a personal consideration or the auditor's perspective in response to information relating to audit responsibilities and risks that will face the auditor who will influence the making of the auditor's final opinion on the report the finances of an entity." "An accountant (auditor) in the audit process gives an opinion with judgment based on past, present and future events"[22]. If an auditor has high knowledge, then judgment will be given the better. In addition to knowledge, the experience can also affect an auditor's ability to give judgment by predicting fraud what happens in the company.

\subsection{Effect of Independence on Audit Judgment}

An auditor honesty is mandatory to be trusted with other parties as an individualistic and should not have any obligations and interests to customers, be it management or owner [1],[6],[23] Research indicates that independence of an auditor positively impacts audit judgement. Audit results become more accurate and precise when there an auditor is highly independent and precise the audit results will be. Independent auditors are those who do not pay attention to the nature of kinship with clients, namely independence in line with audit judgment. When independence increases, audit judgment will increase. When the auditor loses his or her independence, it will affect audit judgment. This is in line with the statement in the second general standard of auditing that "In all matters relating to engagement, independence in mental attitudes must be maintained by the auditor". [25]. Therefore, the following hypothesis is formulated. 
H1: Independence has a positive effect on audit judgment.

\subsection{Effect of Competence on Audit Judgment}

Auditor competence is the auditor's ability to objectively and accurately audit, paying attention to information. More educated auditors have additional knowledge in their fields, making them deeply understand problems. Additionally, they can easily follow complex developments resulting into quality reports. [26] [26]. The results of a study conducted by [27] indicates how competence positively affects audit judgement. The higher the competence of the auditor, the more appropriate the judgment taken by the auditor. On the other hand [26] show that the impacts of competency on audit quality are statistically insignificant. Therefore, the hypothesis is formulated as follows:

$\mathrm{H} 2$ : Competence has a positive effect on audit judgment

\subsection{Effect of Experience on Audit Judgement}

Experienced auditors can do a better job than inexperienced auditors. Experience building abilities, both technically and psychology [28]. During the audit process, the auditor must acquire sufficient business knowledge to classify and understand events, and transactions that may impact the audited financial statements. Experienced auditors do not easily trust information that supports the interests of the company. The auditor will access the information thoroughly when there is some persuasion from management. [26]. The results of a study conducted by [29] [1] [3] states the positive effects of experience on audit judgement. Therefore, the more experienced an auditor is, the easier they solve and anticipate problems during auditing. Experienced auditors can tell upcoming risks, minimize irrelevant information during judgement and facilitate consensus achievements. According to the explanation offered above, the following hypothesis is formulated

H3: Experience impacts judgement positively.

\subsection{Task Complexity moderates and weakens the relationship of independence, competence, and experience on audit judgment}

The high task complexity can complicate the auditor's judgment. Dr. Edwin Locke's (1968) 'Toward a Theory of Task Motivation and Incentives' shows a relationship between goals and one's performance on tasks. This theory can explain that auditors who do not know the purpose and intent of their duties will have difficulty when faced with task complexity. Task complexity is the variety of interrelated and confusing tasks that lead to poor audit judgment. A study conducted by [30] show that task complexity moderates and weakens the relationship of independence on audit judgment. [31] [32]. show that The task complexity variable also weakens the audit experience on audit judgment. These means that task complexity is also a factor that affects the performance in making decisions. Task complexity can be interpreted as the complexity or number of tasks that are diverse, different, and interrelated with each other. Therefore, hypothesis is formulated as follows

H4 : Task Complexity moderates and weakens the relationship of independence on audit judgment.

H5 : Task Complexity moderates and weakens the relationship of competence on audit judgment 
H6: Task Complexity moderates and weakens the relationship of experience on audit judgment

\section{METHODS}

The direct and interaction effects of independence, competence, experience on audit judgement performance and the moderator variable (task complexity) are evaluated using multiple regression analysis and are simultaneously regressed on audit judgement performance. A total of 130 auditors were used as samples with primary source of data obtained from respondents' directly (form Bit.ly). The respondents involved senior and junior auditors with S 1 and 2 education level from Public Accounting Firm (KAP) in the DKI Jakarta.

\subsection{Research Variables}

The Variable used in this research are as follow:

a) Dependent Variable (Y)

The correct responses on audit tasks was used to measure audit judgement performance. Less complex task judgement performance was evaluated depending on the correct answers percentage to question. The number of correct responses on the audit task was used to measure audit judgement. Percentage on the correct answers to questions on audit objectives was used to measure judgement performance, while those with complex task were determined depending on correct answer percentage to substantive questions and compliance tests. Every tasks score was pre-determined depending on developed answers from series of discussions by professional and senior academics.

b) Independent Variable (X)

1. Independence, auditors independence can be easily told from the auditor's intellectual honesty level IAPI (2011, SA Seksi 220, PSA No. 4, p. 220.1). An auditor has to be free from their client's obligations and have zero business with them [26] to be declared as an independent individual. Their independence can be gauged using indicator, implementation of work and independence report.

2. Competence, the enough education and experience earned by an accountant and editors is known as competency. Public accountants must have knowledge in accounting during auditing process [26]. Indicators, general knowledge and unique skills can be used to measure an auditor's competency.

3. Experience, this is the experience earned by an auditor through auditing company's financial statements. Auditors gain much experience and knowledge the more they work on complex things [33]. These experiences can be gauged using the working period and the cases worked on.

c) Moderator Variable (Z)

Through the individuals indicators concerning a task, one is able to measure the complexity. This variable is mainly influenced by individuals competency and the order of the task.

Using Likert scale having 5 choices, respondents will be required to provide answers where $1=$ Strongly disagree (SD), 2= Disagree(D), 3=Neutral (N), 4=Agree (A) and 5= Strongly Agree(SA). 
Four equations were constructed and tested by estimating the Moderated Regression Analysis as follows :

$$
Y=\alpha+\beta_{1} X_{1}+\beta_{2} X_{2}+\beta_{3} X_{3}+\beta_{4} X_{1} X_{4}+\beta_{5} X_{2} X_{4}+\beta_{6} X_{3} X_{4}+e
$$

Description:

$\begin{array}{ll}\mathrm{Y} & : \text { Audit Judgment } \\ \alpha & : \text { Constant } \\ \beta_{1}-\beta_{6} & : \text { Coefficient } \\ \mathrm{X} 1 & : \text { Independence } \\ \mathrm{X} 2 & : \text { Competence } \\ \mathrm{X} 3 & : \text { Experience } \\ \mathrm{X} 4 & : \text { Task Complexity } \\ \mathrm{e} & : \text { Error }\end{array}$

\subsection{Descriptive Statistical Test}

Table 1. Descriptive Statistics

\begin{tabular}{lccccc}
\hline & N & Minimum & Maximum & Mean & Std. Deviation \\
\hline Independence & 115 & 22.00 & 35.00 & 31.7739 & 3.53940 \\
Competence & 115 & 27.00 & 40.00 & 36.1478 & 3.92974 \\
Experience & 115 & 29.00 & 40.00 & 36.2087 & 3.57009 \\
Task Complexity & 115 & 11.00 & 20.00 & 17.9304 & 2.30834 \\
Audit Judgment & 115 & 12.00 & 20.00 & 17.5826 & 2.10256 \\
Valid N (listwise) & 115 & & & & \\
\hline
\end{tabular}

Table 1. Showing the number of respondents as many as 115 respondents, independent variables have an average score (mean) of 31.77, competence 36.14, auditor experience 36 . 20, task complexity 17.93, and audit adjustment 17.58 .

\subsection{Validity Test}

The validity test is conducted to test the validity level of each construct, whether the correlation of each question item with its total score using the Pearson Correlation method. Here are the results of validity tests that have been conducted:

Table 2. Validity

\begin{tabular}{llccc}
\multicolumn{5}{c}{ Table 2. Validity } \\
\hline No. & \multicolumn{1}{c}{ Variable } & $\begin{array}{c}\text { SIG } \\
\text { (2tailed) }\end{array}$ & Terms & Description \\
\hline 1. & Independence $\left(\mathrm{X}_{1}\right)$ & 0.000 & $<0.5$ & Valid \\
2. & Competence $\left(\mathrm{X}_{2}\right)$ & 0.000 & $<0.5$ & Valid \\
3. & Experience $\left(\mathrm{X}_{3}\right)$ & 0.000 & $<0.5$ & Valid \\
4. & Task Complexity $\left(\mathrm{X}_{4}\right)$ & 0.000 & $<0.5$ & Valid \\
5. & Audit Judgment & 0.000 & $<0.5$ & Valid \\
\hline \multicolumn{5}{c}{ Source: Data Processing }
\end{tabular}

Based on table 4.2 above, the overall variable independence, competence, auditor experience, complexity of tasks, and audit judgment has a value of sig $0.000<0.05$ which means valid, testing can be continued. 


\subsection{Realibility Test}

The reliability test is applied to determine the consistency of respondents' responses over time to statements. The method used by Cronbach's Alpha.

Table 3. Realibility Test

\begin{tabular}{lccc}
\hline \multicolumn{1}{c}{ Variable } & Number of Items & Cronbach's Alpha (>0.6) & Decision \\
\hline Independence & 7 & 0.866 & Reliable \\
Competence & 8 & 0.906 & Reliable \\
Experience & 8 & 0.862 & Reliable \\
Task Complexity & 4 & 0.878 & Reliable \\
Audit Judgment & 4 & 0.629 & Reliable \\
\hline
\end{tabular}

Source: Data Processing (Attachment)

Based on table 4.3 above, the overall variable of independence, competence, auditor experience, task complexity, and audit judgement has a value of Cronbach's alpha (CA) of $0.000>0.6$ which means reliable, respondent answers are consistent and reliable.

\subsection{Hypothesis Test}

Table 4. Model Summary ${ }^{\mathrm{b}}$

\begin{tabular}{lcccc}
\hline Model & R & R Square & Adjusted R Square & Std. Error of the Estimate \\
\hline 1 & $.666^{\text {a }}$ & .443 & .428 & 1.58960 \\
\hline a. Predictors: (Constant), & & \\
b. Dependent Variable: & & &
\end{tabular}

The results of the determination coefficient (adjusted $R^{2}$ ) the size of the adjusted $\mathrm{R}$ square is 0.428 , which indicates $42.8 \%$ of independent variables and moderation variables studied namely independence, competence, auditor experience, and task complexity has a contribution of $42.8 \%$ to explain the dependent variable that is audit judgement. The remaining $57.2 \%$ were affected by other variables outside.

\subsection{Simultaneous Test (F Test)}

Table 5. ANOVA $^{\mathrm{a}}$

\begin{tabular}{ccccccc}
\hline & Model & Sum of Squares & df & Mean Square & F & Sig. \\
\hline 1 & Regression & 223.487 & 3 & 74.496 & 29.482 & $.000^{\mathrm{b}}$ \\
& Residual & 280.479 & 111 & 2.527 & & \\
& Total & 503.965 & 114 & & & \\
\hline
\end{tabular}

a. Dependent Variable:

b. Predictors: (Constant),

The simultaneous tests (test F) in F counted by 29,482 with a significance level of $0.000<$ 0.05 , then $\mathrm{H} 0$ rejected $(\mathrm{Ha})$ is accepted, it indicates that the variables of independence, competence, auditor experience, and moderate complexity of tasks together have a significant effect on audit judgment. 


\subsection{Partial Test (t-Test)}

Table 6. (t-Test)

\begin{tabular}{|c|c|c|c|c|c|c|}
\hline Model & Prediction & Beta & $\begin{array}{l}\text { Sig. } \\
\text { 2-tail }\end{array}$ & $\begin{array}{l}\text { Sig } \\
\text { 1-tail }\end{array}$ & Decision & Conclusion \\
\hline (Constant) & & 2.971 & & & & \\
\hline Independence & Positive $(+)$ & 0.166 & 0.008 & 0.004 & $\mathrm{H}_{\mathrm{a}}$ Accepted & There is a positive influence \\
\hline Competence & Positive $(+)$ & -0.063 & 0.420 & 0.210 & $\mathrm{H}_{\mathrm{a}}$ Rejected & $\begin{array}{l}\text { There is no positive } \\
\text { influence. }\end{array}$ \\
\hline Experience & Positive $(+)$ & 0.320 & 0.000 & 0.000 & $\mathrm{H}_{\mathrm{a}}$ Accepted & There is a positive influence \\
\hline INDKOMTGS & Positive $(+)$ & 0.178 & 0.013 & 0.0065 & $\mathrm{H}_{\mathrm{a}}$ Accepted & $\begin{array}{l}\text { Not } \\
\text { weakening/strengthening }\end{array}$ \\
\hline KOMPKOMTGS & Positive $(+)$ & -0.066 & 0.443 & 0.2215 & $\mathrm{H}_{\mathrm{a}}$ Rejected & Weakening \\
\hline PEAUDITKOMTGS & Positive $(+)$ & 0.395 & 0.000 & 0.000 & $\mathrm{H}_{\mathrm{a}}$ Rejected & $\begin{array}{l}\text { Not } \\
\text { weakening/strengthening }\end{array}$ \\
\hline
\end{tabular}

Source: Data Processing

From table 4.6 above, the regression equation model obtained by the constant-coefficient and variable could be included in the regression equation model as follows:

$Y=2,971+0,166 X_{1}-0,063 X_{2}+0,320 X_{3}+0,178 X_{1} X_{4}-0,066 X_{2} X_{5}+0,395 X_{3} X_{6}+\varepsilon$

Keterangan :

$\mathrm{Y} \quad$ : Audit Judgment

$\mathrm{X}_{1}$ : Independence

$\mathrm{X}_{2}$ : Competence

$\mathrm{X}_{3}$ : Experience

$\mathrm{X}_{4}$ : Task Complexity

$\varepsilon \quad:$ error

\section{Results and Discussion}

Variable independence (X1) measured by the following indicators work implementation and reporting independence. Table 4.6 present the significance value for the independent variable is 0.004 smaller than 0.05 , then $\mathrm{H} 01$ is rejected and Hal is accepted therefore the independent variable has a positive effect on the audit judgment. This indicates that Independence is an attitude that is not easily influenced and does not favor anyone. The auditor must have an attitude of independence because if they do not have it can cause errors or fraud in his work. Auditors are trusted by the public to assess the company's financial statements. If the auditor does not have an attitude of independence then the public will find it difficult to trust the performance of the auditor. Therefore, all auditors must have an attitude of independence in order to produce a good audit judgment. This study is appropriate with [26], [6], [1], which showed the positive effect of independence on audit judgement. Auditors produce accurate judgement depending on the level of independence. This results are appropriate with the theory of attitudes and behavior, where this theory explains that auditors

Variable competence (X2) can be measured by the following indicators: General Knowledge and Special skills. Based on table 4.6 above, it indicates that the significance value for the competency variable is 0.210 where the value is greater than 0.05 , then $\mathrm{H} 02$ is accepted and $\mathrm{Ha} 2$ is rejected therefore the competency variable does not affect the audit 
judgment. Hypothesis indicating that audit quality is affected is rejected. An auditor is termed competent if they have quality, general and unique knowledge. Nevertheless, it is not assured since more knowledge obtained from specific areas is still required. Individuals creates ideas concerning their states, affecting character in attribution theory. Results [26] stated that auditor competence does not influence audit quality while the results [27] illustrated how the positive impact competence has to audit judgement. The audit judgment was taken by the auditor is better and more appropriate. Skills and knowledge are acquired through education and participation in training or seminars on accounting practices and auditing technique

Variable experience (X3) can be measured by the following indicators: The length of time working as an auditor, and the number of cases worked. Table 4.6 above illustrates that 0.000 is a significant value experience for auditors. When the value is less than $0.05, \mathrm{HO} 3$ is rejected and $\mathrm{Ha} 3$ accepted. This results into a conclusion that the auditor experience variable affecting audit judgement positively. The auditor will study the mistakes of the past in order to make a better judgment with time. Generally, high audit quality are gained from more experienced auditors [28], [17]. An experience auditor will do great job compared to the inexperienced one. Essentially, experience involves skills development technically and psychologically. Auditing encounters several cases by auditors whose experiences can be measured using editor's framework and criteria of examining the financial statements. High and quality audits are resulted from how much experienced an auditor is. [34].

Variable $(Z)$ is gauged using indicators of people perception of task difficulty resulted from self-competency and task structure. Table 4.6 presents the significance value for the independence variable having task complexity is 0.0065 lesser than 0.05 . H04 is denied while $\mathrm{Ha} 4$ is accepted concluding that the independence on judgement audit is positively affected with task complexity. Table 4.6 also presents the value of significant for competence variables with task complexity is 0,221 greater than 0.05 , then $\mathrm{H} 06$ is accepted and Ha6 is rejected so that it can be concluded that the complexity of the task weaken the effect of the competence on the audit judgment.

Based on table 4.6 above, it can be seen the value of significance for experience variables with task complexity is 0,000 smaller than 0.05 , then $\mathrm{H} 04$ is rejected and $\mathrm{Ha} 4$ is accepted so that it can be concluded that the complexity of the task strengthens the effect of experience on the judgment of the audit. On the other hand, [32] the complexity of the task weaken the effect of the experience of the auditors on audit judgment at a significance level of $5 \%$, If the difficulty task is greater than the individual's ability, it will trigger fears of failure in completing the task. The auditor's experience will be weaker on audit judgments taken because they have complexity tasks.

Table 7. List of Statements for Independence Variables

\begin{tabular}{|c|c|c|c|c|c|c|}
\hline \multirow[t]{2}{*}{ NO } & \multirow[t]{2}{*}{ STATEMENT } & \multicolumn{5}{|c|}{ SCORE } \\
\hline & & STS & TS & $\mathbf{N}$ & $\mathbf{S}$ & SS \\
\hline \multicolumn{7}{|c|}{ How do you think about the following statements? } \\
\hline \multicolumn{7}{|c|}{ I. Indicator : Independence of Work Implementation } \\
\hline 1. & $\begin{array}{l}\text { As an auditor I conducted an examination without } \\
\text { coercion and was free from all interests. }\end{array}$ & & & & & \\
\hline 2. & $\begin{array}{l}\text { As an auditor I refuse to accept audit assignments if at } \\
\text { the same time I have a cooperation relationship with } \\
\text { the parties examined. }\end{array}$ & & & & & \\
\hline 3. & $\begin{array}{l}\text { As my auditor in determining opinions on financial } \\
\text { statements, there is no pressure from anyone. }\end{array}$ & & & & & \\
\hline
\end{tabular}




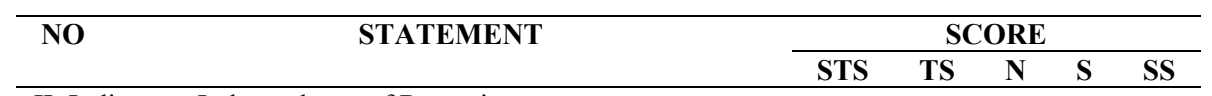

II. Indicator : Independence of Reporting

1. As an auditor, I am free from the efforts of certain parties to influence the consideration of the examination of the contents of the examination report.

2. As an auditor, I am free from the obligations of others to influence the facts to be reported.

3. The number of audit fees I received as an auditor in the assignment did not affect the disclosure of the findings.

4. As an auditor, I will continue to disclose client fraud in reporting even though there is a possibility that the client will make an auditor's replacement.

Table 8. List of Statements for Competency Variables

\begin{tabular}{|c|c|c|c|c|c|c|}
\hline \multirow[t]{2}{*}{ NO } & \multirow[t]{2}{*}{ STATEMENT } & \multicolumn{5}{|c|}{ SCORE } \\
\hline & & STS & TS & $\mathbf{N}$ & $\mathbf{S}$ & SS \\
\hline \multicolumn{7}{|c|}{ What do you think about the following revelations? } \\
\hline \multicolumn{7}{|c|}{ I. Indicator : General Knowledge } \\
\hline 1. & $\begin{array}{l}\text { As an auditor, I need to be able to conduct analytical } \\
\text { reviews. }\end{array}$ & & & & & \\
\hline 2. & $\begin{array}{l}\text { As an auditor, I must understand the Financial } \\
\text { Accounting Standards (SAK) and the Professional } \\
\text { Standards of Public Accountants (SPAP). }\end{array}$ & & & & & \\
\hline 3. & $\begin{array}{l}\text { To do a good audit I need to know the type of client } \\
\text { company. }\end{array}$ & & & & & \\
\hline & $\begin{array}{l}\text { To do a good audit, as an auditor I need knowledge } \\
\text { gained from the education level (D3, S1, S2, S3). }\end{array}$ & & & & & \\
\hline \multicolumn{7}{|c|}{ II. Indicator : Special Skills } \\
\hline 1. & $\begin{array}{l}\text { As an auditor, I was able to create an audit report and } \\
\text { present it well. }\end{array}$ & & & & & \\
\hline 2. & $\begin{array}{l}\text { The specific expertise I have as an auditor can support } \\
\text { the results of the audits I conduct. }\end{array}$ & & & & & \\
\hline 3. & $\begin{array}{l}\text { As an auditor, I must understand the science of } \\
\text { statistics and have expertise in using computers. }\end{array}$ & & & & & \\
\hline 4. & $\begin{array}{l}\text { As an auditor, I must have the expertise to conduct } \\
\text { interviews as well as the ability to read quickly. }\end{array}$ & & & & & \\
\hline
\end{tabular}

Table 9. List Of Statements For Auditor Experience Variables

\begin{tabular}{llllllr}
\hline NO & STATEMENT & \multicolumn{4}{c}{ SCORE } \\
\cline { 3 - 6 } & & SD & D & N & A \\
& & & & & SA \\
\hline
\end{tabular}

How do you think about the following statements?

I. Indicator : Length of Work

1. The longer I become an auditor, the more I understand how to deal with an entity/object of examination in obtaining the data and information required.

2. The longer I work as an auditor, the more I can comprehend the relevant information to take into consideration in making decisions.

3. The longer I work as an auditor, the more able to identify errors made by the inspection object. 


\begin{tabular}{|c|c|c|c|c|c|c|}
\hline \multirow[t]{2}{*}{ NO } & \multirow[t]{2}{*}{ STATEMENT } & \multicolumn{5}{|c|}{ SCORE } \\
\hline & & \multirow[t]{2}{*}{ SD } & $\mathbf{D}$ & $\mathbf{N}$ & \multicolumn{2}{|r|}{$\begin{array}{r}\text { A } \\
\text { SA }\end{array}$} \\
\hline 4. & $\begin{array}{l}\text { The longer I become an auditor, the easier it is to } \\
\text { determine the cause of the error and provide } \\
\text { recommendations to minimize the cause. }\end{array}$ & & & & & \\
\hline \multicolumn{7}{|c|}{ II. Indicator: Frequency of Work Done } \\
\hline \multicolumn{7}{|c|}{$\begin{array}{l}\text { 1. The number of audit tasks makes me need } \\
\text { thoroughness and accuracy in completing it. }\end{array}$} \\
\hline 2. & $\begin{array}{l}\text { Errors in the collection and selection of evidence and } \\
\text { information can hinder me in the process of } \\
\text { completing the work. }\end{array}$ & & & & & \\
\hline 3. & $\begin{array}{l}\text { The sheer number of tasks at hand gave me the } \\
\text { opportunity to learn from the failures and successes I } \\
\text { had experienced. }\end{array}$ & & & & & \\
\hline 4. & $\begin{array}{l}\text { The number of tasks received can spur me to get the } \\
\text { job done quickly and without a buildup of tasks. }\end{array}$ & & & & & \\
\hline \multirow{3}{*}{ NO } & Table 10. List of Questions for Task Comple & xity $V_{c}$ & iables & & & \\
\hline & STATEMENT & & & ORI & & \\
\hline & & STS & TS & $\mathbf{N}$ & $\mathbf{S}$ & SS \\
\hline \multicolumn{7}{|c|}{ What do you think of the following question? } \\
\hline \multicolumn{7}{|c|}{ I. Indicator: Difficulty of tasks } \\
\hline 1 & $\begin{array}{l}\text { In carrying out my duties, I know clearly the task } \\
\text { done. }\end{array}$ & & & & & \\
\hline 2 & $\begin{array}{l}\text { In carrying out my duties I know clearly that a task } \\
\text { has been completed. }\end{array}$ & & & & & \\
\hline \multicolumn{7}{|c|}{ II. Indicator: Task Structure } \\
\hline 1 & $\begin{array}{l}\text { In carrying out my duties I know clearly that I will } \\
\text { later do a special task. }\end{array}$ & & & & & \\
\hline 2 & $\begin{array}{l}\text { In carrying out my duties I know how to do each type } \\
\text { of task given to me. }\end{array}$ & & & & & \\
\hline \multirow{3}{*}{ NO } & Table 11. List of Questions for Variable A & udit Ju & lgeme & & & \\
\hline & STATEMENT & & & $\overline{\text { ORE }}$ & & \\
\hline & & STS & TS & $\mathbf{N}$ & $\mathbf{S}$ & SS \\
\hline \multicolumn{7}{|c|}{ What do you think of the following question? } \\
\hline \multicolumn{7}{|c|}{ I. Indicator: Level of Audit Risk } \\
\hline 1 & $\begin{array}{l}\text { In providing judgment on the results of the audit, as } \\
\text { an auditor, I should consider the inherent risks } \\
\text { associated with the account balance. }\end{array}$ & & & & & \\
\hline 2 & $\begin{array}{l}\text { In providing audit judgment, as an auditor, I am } \\
\text { required to establish the risk of control in a particular } \\
\text { account balance. }\end{array}$ & & & & & \\
\hline \multicolumn{7}{|c|}{ II. Indicator: Survival of an entity (going concern) } \\
\hline 1 & $\begin{array}{l}\text { In providing an audit judgment on the results of the } \\
\text { audit, the auditor must consider the survival of a } \\
\text { company (going concern). }\end{array}$ & & & & & \\
\hline 2 & $\begin{array}{l}\text { In determining the provision of judgment audit is } \\
\text { based on the ability of management in assessing a } \\
\text { financial statement. }\end{array}$ & & & & & \\
\hline
\end{tabular}




\section{References}

[1] I. Ismunawan and E. Triyanto, "Faktor-Faktor Penentu Audit Judgement Pada Kantor Akuntan Publik (Kap Di Surakarta Dan Yogyakarta)," J. Akunt. dan Pajak, vol. 20, no. 2, pp. 224-229, 2020, doi: 10.29040/jap.v20i2.722.

[2] I. N. Noor, E. Pujianthi, and M. Hamun, "Effect Of Audit Expertise, Compliance Pressure, Task Complexity, And Experience On Audit Judgement," Mega Akt. J. Ekon. dan Manaj., vol. 8, no. 2, pp. 100-112, (2019), https://megaaktiva.umkendari.ac.id/index.php/Jurnal\%0AEFFECT.

[3] I. E. Riantono, "Faktor-Faktor Yang Mempengaruhi Audit Judgment: Studi Empiris Big Four Di Jakarta,” J. Kaji. Akunt., vol. 2, no. 2, pp. 178-194, (2018), doi: 10.33603/jka.v2i2.1747.

[4] G. Gendrianto, B. Rustandi, and T. Z. Mutaqien, "Faktor-Faktor Yang Mempengaruhi Audit Judgment," J. SIKAP (Sistem Informasi, Keuangan, Audit. Dan Perpajakan), vol. 3, no. 1, pp. 37-48, (2018), doi: 10.32897/jsikap.v3i1.98.

[5] T. M. Iskandar and Z. M. Sanusi, "Assessing the effects of self-efficacy and task complexity on internal control audit judgment," Asian Acad. Manag. J. Account. Financ., vol. 7, no. 1, pp. 29-52, (2011).

[6] E. Sihombing and V. Siagian, "Pengaruh Keahlian Auditor dan Independensi terhadap Audit Judgment," J. Ilm. Mhs. Manajemen, Bisnis dan Akunt., vol. 2, no. 5, pp. 741751, (2020), doi: 10.32639/jimmba.v2i5.660.

[7] K. Takemura, Behavioral decision theory. Psychological and mathematical descriptions of human choice behavior. (2014).

[8] T. A. Safi'i and P. Y. Jayanto, “Analisis Faktor-Faktor Yang Berpengaruh Terhadap Audit Judgement," Account. Anal. J., vol. 4, no. 4, pp. 1-19, (2015), doi: 10.15294/aaj.v4i4.9114.

[9] A. Gracea, L. Kalangi, and S. Randonuwu, "Pengaruh Keahlian Auditor, Pengetahuan Auditor Dan Kompleksitas Tugas Terhadap Audit Judgment (Studi Kasus Pada BPK RI Perwakilan Provinsi Sulawesi Utara)," J. EMBA J. Ris. Ekon. Manajemen, Bisnis dan Akunt., vol. 5, no. 2, pp. 2627-2636, (2017).

[10] Institut Akuntan Publik Indonesia. (IAPI), Standar Profesional Akuntan Publik (Public Accountants Professional Standards). Jakarta: salemba empat, (2011).

[11] F. Gita A, Pengaruh Kompetensi Sumber Daya Manusia, Penerapan Sistem Akuntansi Keuangan Daerah (SAKD), Pemanfaatan Teknologi Informasi, dan Sistem Pengendalian Intern Terhadap Kualitas Laporan Keuangan Pemerintah Daerah (Studi Empiris Pada SKPD Kabupaten Sleman). (2017).

[12] R. Agusti and N. P. Pertiwi, "Pengaruh Kompetensi, Independensi Dan Profesionalisme Terhadap Kualitas Audit (Studi Empiris Pada Kantor Akuntan Publik Se Sumatera)," (2013).

[13] W. F. Meixner and R. B. Welker, "Judgment consensus and auditor experience: An examination of organizational relations," Account. Rev., vol. 13, no. 3, pp. 505-513, (1998), [Online]. Available: http://dx.doi.org/10.1016/j.jaci.2012.05.050.

[14] M. Sila, B. Subroto, Z. Baridwan, \& Aulia, and F. Rahman, "The Effect of Knowledge and Experience on Professional Auditor's Judgment: Study on State Auditor in Indonesia," Int. J. Manag. Adm. Sci., vol. 3, no. 10, pp. 98-106, (2016), [Online]. Available: www.ijmas.orgwww.ijmas.org.

[15] T. G. Gill and W. F. Murphy, "Task complexity and design science," IMSCI 2011 - 5th Int. Multi-Conference Soc. Cybern. Informatics, Proc., pp. 105-109, 2011. 
[16] A. A. Arens, R. J., E. M. S., Beasley, and C. E. Hogan, Auditing and Assurance Service 16th Edition. Jakarta: Erlangga, (2017).

[17] S. Pektra and R. Kurnia, "Pengaruh Gender, Kompleksitas Tugas, Tekanan Ketaatan, Pengalaman Auditor Terhadap Audit Judgement," J. Ultim. Account., vol. 7, no. 1, pp. 1-20, (2015), doi: 10.31937/akuntansi.v7i1.79.

[18] R. A. Puspitasari and D. Daljono, "Analisis Pengaruh Gender, Tekanan Ketaatan, Kompleksitas tugas, dan Pengalaman Terhadap Kinerja Auditor Dalam Pembuatan Audit Judgment," Universitas Diponegoro, (2011).

[19] T. M. Iskandar, N. S. Ria, M. . Zuraidah, and A. Rita, "Enchanging Auditor Judgment Through Motivational Factors.," in Penerbit Kertas Diskusi Fakultas Ekonomi dan Perniagaan, (2010).

[20] E. Wibowo, "Learning Analysis Auditing Courses (Competence in Audit Judgment)," vol. 1, no. 2, pp. 1-25, (2011).

[21] A. Rakhmalia, "Effect of Knowledge, Experience and Ethical Orientation On the Audit Judgment with Ethical Decision Making as Intervening Variables (Study at the Public Accounting Firm In Central Java)," Semarang State University, (2013).

[22] M. D. Sitinjak, H. Agustiawati, and I. Petrus, "Using Debate To Improve Studentsâ€ $€^{\mathrm{Tm}}$ Vocabulary And Speaking Achievements," J. English Lit. Educ. Teach. Learn. English as a Foreign Lang., vol. 2, no. 2, pp. 26-37, (2015).

[23] T. Sitanggang, "The Influence Of An Auditor's Expertise, Obedience Pressure, And Independence On Audit Judgment," Int. J. Contemp. Account., vol. 2, no. 1, pp. 1-16, (2020).

[24] R. Agusti and N. P. Pertiwi, "Pengaruh Kompetensi, Independensi, Profesionalisme Terhadap Kualitas Audit,” J. Ekon., vol. 21, no. 3, pp. 1-13, (2013), doi: 10.22441/tekun.v8i1.5528.

[25] F. Alamri, G. B. Nangoi, and J. Tinangon, "Pengaruh Keahlian, Pengalaman, Kompleksitas Tugas dan Independensi terhadap Audit Judgement Auditor Internal pada Inspektorat Provinsi Gorontalo,” J. EMBA, vol. 5, no. 2, pp. 593-601, (2017), [Online]. Available: https://ejournal.unsrat.ac.id/index.php/emba/article/view/15731.

[26] G. S. Ningrum and L. K. Wedari, "Impact Of Auditor's Work Experience, Independence, Objectivity, Integrity, Competency And Accountibility On Audit Quality," J. Econom., vol. 1, no. 1, pp. 19-33, (2002).

[27] M. Yusuf, "Pengaruh Kompetensi, Tekanan Ketatan dan Kompleksitas Terhadap Audit Jutdgment," J. Akunt. dan Manaj., vol. 13, no. 01, pp. 167-185, (2017).

[28] E. M. Singgih and I. B. Bawono, "Pengaruh Independensi, Pengalaman, Due Professional Care Dan Akuntabilitas Terhadap Kualitas Audit (Studi pada Auditor di KAP 'Big Four' di Indonesia)," Simp. Nas. Akutansi XIII Purwokweto, pp. 1-24, (2010).

[29] M. M. O. L. Sofiani and E. Tjondro, "Pengaruh Tekanan Ketaatan, Pengalaman Audit , Dan Audit Tenure Terhadap Audit Judgement," Tax Account. Rev., vol. 4, no. 1, pp. 1-10, (2014).

[30] Hasnidar, "Pengaruh Self-Efficacy, Tekanan Ketaatan Dan Independensi Auditor Terhadap Audit Judgment Dengan Kompleksitas Tugas Dan Moral Reasoning Sebagai Variabel Moderasi," (2018).

[31] H. Andryani, E. Piturungsih, and L. M. Furkan, "Pengaruh Tekanan Ketaatan, Keahlian Audit Dan Pengalaman Audit Terhadap Audit Judgment Dengan Kompleksitas Tugas Sebagai pemoderasi," J. Ris. Akunt. Aksioma, vol. 18, no. 2, pp. 79-115, (2019), [Online]. Available: http://aksioma.unram.ac.id/index.php/aksioma/article/view/83. 
[32] S. Ayudia, "Pengaruh Tekanan Ketaatan, Pengetahuan, Dan Pengalaman Auditor Terhadap Audit Judgment dengan Komplek tugas sebagai Variabel Moderationg," JOM Fekon, vol. 2, no. 2, pp. 1-15, (2015), doi: 10.21107/infestasi.v14i2.4870.

[33] P. S. Futri and G. Juliarsa, "Pengaruh Independensi, Profesionalisme, Tingkat Pendidikan, Etika Profesi, Pengalaman, Dan Kepuasan Kerja Auditor Terhadap Kualitas Audit Pada Kantor Akuntan Publik Di Bali," E-Jurnal Akunt. Univ. Udayana, vol. 8, no. 1, pp. 41-58, (2014).

[34] A. A. Arens, R. J. Elder, and M. S. Beasley, Auditing and Assurance Services, 14 th. New Jersey: Pearson Education Inc., (2012). 